\title{
Evaluasi Efek Relationship Marketing Pada Pelayanan Skin Care di Rumah Sakit PKU Muhammadiyah Yogyakarta
}

\section{The Evaluation of Relationship Marketing of Skin Care Services at Pku Muhammadiyah Yogyakarta Hospital}

\author{
Nasiatul Aisyah Salim, Susilowati, Ari Probandari
}

\section{Magister Manajemen Rumah Sakit Universitas Gadjah Mada Yogyakarta}

\begin{abstract}
ABSTRAK
Layanan perawatan kulit merupakan layanan yang digunakan RS PKU Muhammadiyah untuk menyikapi persaingan antar rumah sakit. Dalam setahun, jumlah kunjungan mengalami fluktuatif. Salah satu dampak fluktuatif adalah penilaian negatif dari pasar karena rumah sakit yang tidak dapat mengendalikan pelayanan perawatan kulit. Sehingga salah satu cara untuk mengatasi keadaan yang fluktuatif adalah evaluasi pemasaran dengan berprinsip pada relationship marketing. Penelitian ini bertujuan untuk mengevaluasi relationship marketing pada pelayanan perawatan kulit di RS PKU Muhammadiyah Yogyakarta. Jenis penelitian ini mixed methods dengan desain sekuensial explanatori. Subjek penelitian kuantitatif 112 responden dan subjek penelitian kualitatif 7 responden yang dipilih dari subjek penelitian kuantitatif. Pengambilan data dengan kuesioner dan wawancara mendalam. Data dianalisis dengan regresi linier berganda. Komunikasi memiliki asosiasi terhadap kepercayaan, komitmen dan kepuasan hubungan. Untuk durasi hubungan memiliki asosiasi terhadap komitmen dan kepuasan hubungan. Sedangkan frekuensi interkasi memiliki asosiasi terhadap kepercayaan. Dan untuk informasi dari mulut ke mulut memiliki asosiasi terhadap komitmen dan kepuasan hubungan. Faktor yang mempengaruhi adanya keraguan pelanggan untuk memanfaatkan layanan perawatan kulit adalah pelanggan harus menunggu padahal sudah melakukan sistem perjanjian, beautician tidak dapat menjawab pertanyaan pelanggan, tidak tersedianya obat perawatan kulit di apotek, belum adanya hasil dari perawatan kulit di RS PKU Muhammadiyah Yogyakarta. untuk suksesnya relationship marketing pada pelayanan perawatan kulit di RS PKU Muhammadiyah Yogyakarta, selain komunikasi, durasi hubungan, frekuensi interaksi, kepercayaan, komitmen, kepuasan hubungan dan informasi dari mulut ke mulut perlu meningkatkan keahlian penyedia, manfaat hubungan, kesamaan, persepsi harga, kemampuan menghargai pelanggan dan kualitas pelayanan.
\end{abstract}

Kata kunci: Evaluasi, Relationship Marketing, Pelayanan Perawatan Kulit

\begin{abstract}
Skin care is a service which is taken into account by PKU Muhammadiyah Yogyakarta hospital as a way to cope with the competition among the hospitals. PKU Muhammadiyah Yogyakarta skin care was established in July, 2010. In a year, visit amount had fluctuated. One fluctuated impact is negative evaluation of market because hospital can not control skin care service. marketing evaluation a principles on relationship marketing. Handled fluctuated way of marketing evaluation principled on relationship marketing. To evaluate of relationship marketing on skin care service in PKU Muhammadiyah Yogyakarta Hospital. This research used a mixed method with design sequential explanatory. The subject quantitative is 112 respondents and subject qualitative is 7 respondents selected from subject quantitative. The data was taken from questionnaires and in-depth interviews. The data analysis is double linear regression. Communication have association on trust, commitment and relationship satisfaction.Relationship duration have association on commitment and relationship satisfaction. Interaction frequency have no association on trust. Commitment and relationship satisfaction have association on word of mouth. Factors affecting no customer commitment is customer must wait whereas did appoitment, beautician can not answer the question of customers, no drugs in pharmacy and no resulting skin care in PKU Muhammadiyah Yogyakarta Hospital. Commitment and relationship satisfaction have association on word of mouth. Communication and relationship duration can increase of commitment and relationship satisfaction.
\end{abstract}

Key words: Evaluate, relationship marketing, skin care service

\section{PENDAHULUAN}

Pelayanan Rumah Sakit (RS) saat ini mengalami persaingan yang ketat karena semakin pandainya masyarakat dalam memilih layanan kesehatan yang berkualitas. Dalam situasi persaingan tersebut, RS dituntut menjadi kreatif dan inovatif dalam menciptakan pelayanan yang unggul untuk menyikapi persaingan antar RS. Dan RS yang berorientasi pada pasar ternyata dapat meningkatkan kinerja RS terutama untuk RS kecil.Layanan perawatan kulit merupakan salah satu layanan yang digunakan RS untuk menyikapi persaingan antar rumah sakit seperti yang dilakukan oleh RS PKU Muhammadiyah Yogyakarta. Dua puluh satu persen responden menginginkan adanya layanan spesialis 
kulit dan kecantikan sebagai bentuk pendirian "Women Health Clinic" di RS PKU Muhammadiyah Yogyakarta. Rumah sakit PKU Muhammadiyah Yogyakarta adalah rumah sakit swasta kelas $\mathrm{C}$ dengan jumlah tempat tidur sebanyak 205. Rumah sakit ini memiliki layanan perawatan kulit yang baru diresmikan pada bulan Juli tahun 2010 yang memisahkan layanan perawatan kulit dengan layanan kulit di poliklinik kulit. Layanan perawatan kulit ini ditangani oleh tiga dokter spesialis kulit dan kelamin dengan satu dokter merupakan dokter tetap dan dua dokter lainnya tidak tetap. Layanan perawatan kulit ini bekerjasama dengan satu produk kecantikan. Terdapat tiga layanan perawatan kulit yaitu pembelian produk kecantikan dari produk yang bekerjasama dengan RS PKU Muhammadiyah Yogyakarta, penanganan BO (Beautician Operator) dan penanganan dokter. Layanan perawatan kulit ini memberlakukan sistem perjanjian untuk kenyamanan pelanggan yang apabila pelanggan ingin memanfaatkan layanan perawatan kulit ini, pelanggan terlebih dahulu mendaftar untuk mendapatkan jadwal waktu.

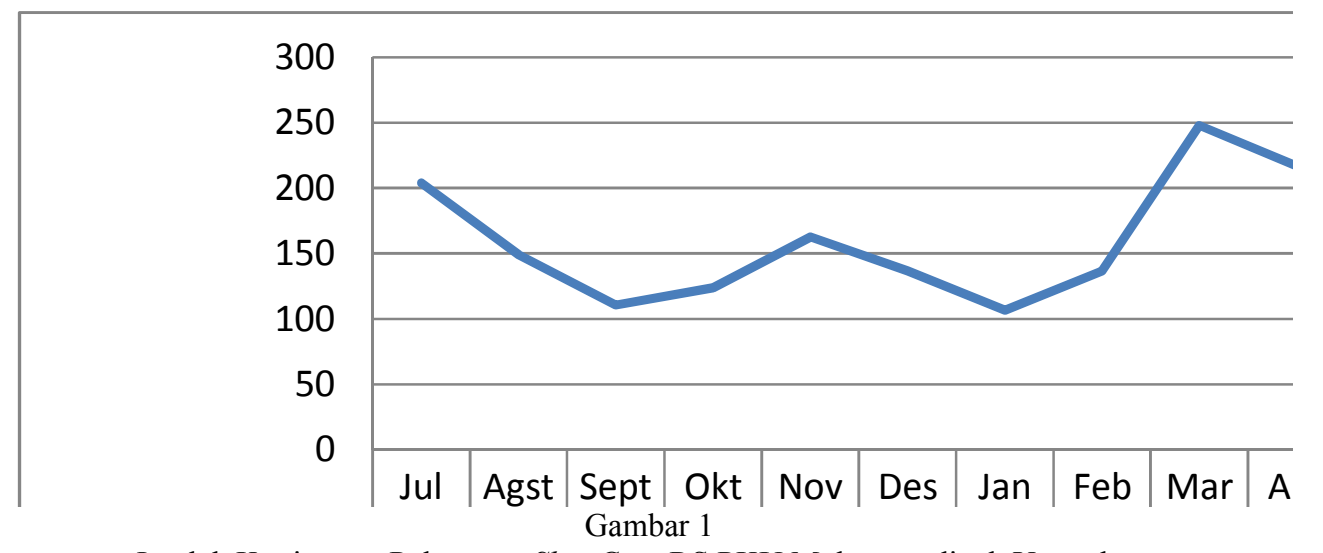

Jumlah Kunjungan Pelayanan Skin Care RS PKU Muhammadiyah Yogyakarta

Bulan Juli 2010 - Juni 2011

Gambar 1 merupakan hasil dari jumlah pengunjung yang datang untuk membeli produk kecantikan, melakukan penanganan $\mathrm{BO}$, penanganan dokter dan pengunjung yang hanya menanyakan mengenai layanan perawatan kulit ke klinik perawatan kulit RS PKU Muhammadiyah Yogyakarta. Gambar 1 menjelaskan bahwa kunjungan pelayanan perawatan kulit dalam setahun mengalami fluktuatif. Keadaan yang fluktuatif ini bisa berdampak pada rumah sakit, salah satunya adanya penilaian negatif dari pasar terhadap rumah sakit yang belum bisa mengendalikan pelayanan perawatan kulit di rumah sakit. Untuk mengendalikannya, dapat dilakukan suatu evaluasi. Evaluasi adalah menilai seluruh kegiatan seobyektif mungkin untuk mengetahui pencapaian tujuan dari yang telah ditetapkan.

Dengan adanya layanan perawatan kulit yang baru diresmikan oleh RS PKU Muhammadiyah Yogyakarta, evaluasi yang dapat dilakukan, salah satunya adalah dengan mengoptimalkan strategi pemasaran secara proaktif. Dan strategi pemasarannya dengan berprinsip pada relationship marketing.

Relationship marketing merupakan segala kegiatan yang ditujukan untuk membangun, mengembangkan dan memelihara hubungan timbal balik dengan konsumen. Relationship marketing merupakan strategi yang digunakan oleh banyak penyedia layanan untuk mempertahankan hubungan jangka panjang. Dengan membangun hubungan jangka panjang antara pelanggan dan penyedia layanan yang berkualitas, kegiatan relationship marketing dapat dikatakan berhasil dan akan menghasilkan hubungan yang kuat dengan pelanggan dan meningkatkan kinerja hasil penjualan. Suksesnya relationship marketing dapat dilihat dari manfaat hubungan, keahlian penjual, komunikasi, komitmen, kepercayaan, kepuasan hubungan, informasi dari mulut ke mulut, keberlanjutan, kesetiaan pelanggan terhadap penjual.

Relationship marketing yang dilakukan layanan perawatan kulit RS PKU Muhammadiyah Yogyakarta adalah penyedia layanan perawatan kulit menjawab semua pertanyaan yang ditanyakan oleh pelanggan, BO memberitahu pelanggan mengenai kapan harus melakukan perawatan kembali, dokter memberitahukan baik tidaknya penanganan yang akan diperoleh oleh pelanggan, bagian administrasi memberikan pesan singkat kepada pelanggan untuk memberitahukan apabila adanya promosi pelayanan perawatan kulit di RS PKU Muhammadiyah Yogyakarta. Untuk meningkatkan kepercayaan dari pelanggan, dokter menangani langsung penanganan perawatan.

\section{METODE}

Jenis penelitian pada penelitian ini adalah mixed methods dengan desain sekuensial explanatori yaitu penelitian yang diawali dengan pengumpulan data kuantitatif dilanjutkan dengan pengumpulan data kualitatif. Subyek penelitian kuantitatif adalah pelanggan skin care yang berada di daerah kota 
Yogyakarta menurut alamat yang tercantum pada data pelanggan karena pelanggan skin care yang paling banyak memanfaatkan layanan skin care di RS PKU Muhammadiyah Yogyakarta berada di Kota Yogyakarta dan banyaknya klinik kecantikan di wilayah kota Yogyakarta. Dan kriteria ekslusi adalah karyawan RS PKU Muhammadiyah yang memanfaatkan layanan skin care, pelanggan skin care yang tidak mencantumkan nomor telepon, dan hanya mengambil satu penggan dalam satu keluarga.

Dari total pelanggan skin care pada bulan Juli 2010 - Agustus 2011 yang berjumlah 838 orang, terpilih 198 orang untuk subjek penelitian kuantitatif. Namun dalam pelaksanaannya, 86 orang tidak bersedia untuk dijadikan responden sehingga yang dijadikan responden dalam penelitian ini sebanyak 112 orang. Pengambilan data dilakukan dengan kuesioner. Data penelitian kuantitatif di analisis secara deskriptif dengan menggunakan analisis regresi linier berganda.

Setiap item dalam kuesioner menggunakan lima skala likert. Pertanyaan untuk variabel komunikasi dimodifikasi dari penelitian Anderson \& Weitz (1992), pertanyaan untuk variabel kepercayaan dimodifikasi dari penelitian Doney \& Cannon (1997), pertanyaan untuk variabel komitmen dimodifikasi dari penelitian Crosby et al (1990), pertanyaan dengan variabel kepuasan hubungan dimodifikasi dari penelitian Reynolds \& Beatty (1999) dan pertanyaan untuk variabel informasi dari mulut ke mulut dimodifikasi dari penelitian Harrison \& Walker (2001).

Subjek penelitian kualitatif adalah responden dari subjek penelitian kuantitatif yang memiliki kesamaan jawaban ragu-ragu dalam memanfaatkan layanan perawatan kulit di RS PKU Muhammadiyah Yogyakarta pada item pertanyaan variabel komitmen (pelanggan merasa memiliki komitmen dengan penyedia, pelanggan berkomitmen melakukan hubungan jangka panjang, pelanggan berniat untuk tetap menggunakan penyedia); kepuasan hubungan (keputusan memanfaatkan layanan di RS PKU Muhammadiyah Yogyakarta adalah benar) dan informasi dari mulut ke mulut (keinginan pelanggan untuk merekomendasikan skin care RS PKU Muhammadiyah kepada orang lain sangat besar). Sehingga terpilih 7 orang dari 112 orang. Pengambilan data kualitatif dilakukan melalui wawancara mendalam yang akan dianalisis dengan membuat transkrip dalam bentuk narasi.

\section{HASIL}

\section{Analisis Univariat}

Hasil penelitian menyatakan bahwa komunikasi antara penyedia layanan dengan pelanggan adalah baik. Walaupun ada pelanggan yang tidak mendapatkan informasi mengenai apa yang terjadi pada kulitnya, penyedia layanan tidak memberikan informasi sebanyak yang ingin ditanyakan dan informasi yang diberikan penyedia layanan tidak jelas. Begitu pula dengan kepercayaan. Pelanggan percaya dengan penyedia layanan walaupun ada pelanggan yang merasa bahwa penyedia layanan tidak menepati janji dan tidak berkompeten.

Untuk komitmen pelanggan terhadap layanan skin care dapat dikatakan baik walaupun 32,1\% pelanggan menjawab ragu-ragu untuk pertanyaan mengenai tidak berencananya pelanggan menggunakan layanan perawatan kulit di tempat lain. Sedangkan untuk kepuasan hubungan, sebagian pelanggan masih memiliki keraguan dalam hubungan yang dekat dengan penyedia layanan dan tidak sepadannya antara hasil yang didapatkan dengan uang yang telah dikeluarkan oleh pelanggan. Dan untuk informasi dari mulut ke mulut, pelanggan masih merasa ragu-ragu untuk merekomendasikan layanan skin care di RS PKU Muhammadiyah Yogyakarta kepada orang lain (36,6 $\%)$

\section{Analisis Bivariat}

Hasil penelitian menunjukkan bahwa durasi hubungan 1-4 kali tidak dapat menghasilkan komitmen yang baik walaupun memiliki kepercayaan dan kepuasan hubungan yang baik. Selain itu semakin lama durasi hubungan maka semakin akan menghasilkan kepercayaan, komitmen dan kepuasan hubungan yang baik. Hasil penelitian juga menunjukkan bahwa frekuensi interaksi 2-7 kali dapat menghasilkan kepercayaan, komitmen dan kepuasan hubungan yang baik. Selain itu, dengan frekuensi interaksi kurang dari 1 kali belum dapat menghasilkan kepercayaan, komitmen dan kepuasan hubungan yang baik.

\section{Analisis Multivariat}

Hasil penelitian menunjukkan bahwa ada asosiasi antara komunikasi dan frekuensi interaksi terhadap kepercayaan. Sehingga dengan meningkatnya komunikasi dan frekuensi interaksi akan menjamin meningkatnya kepercayaan. Hasil penelitian juga menunjukkan bahwa ada asosiasi antara komunikasi dan durasi hubungan terhadap komitmen. Sehingga dengan meningkatnya komunikasi dan durasi hubungan menjamin akan meningkatnya komitmen. Tidak hanya itu saja, hasil penelitian menunjukkan bahwa ada asosiasi antara komunikasi dengan kepuasan hubungan. Sehingga dengan meningkatnya komunikasi menjamin akan diikuti dengan meningkatnya kepuasan hubungan.

Untuk informasi dari mulut ke mulut, hasil penelitian menunjukkan bahwa ada asosiasi antara komitmen dan kepuasan hubungan terhadap informasi dari mulut ke mulut. Sehingga dengan meningkatnya komitmen dan kepuasan hubungan menjamin akan diikuti dengan meningkatnya informasi dari mulut ke mulut. 


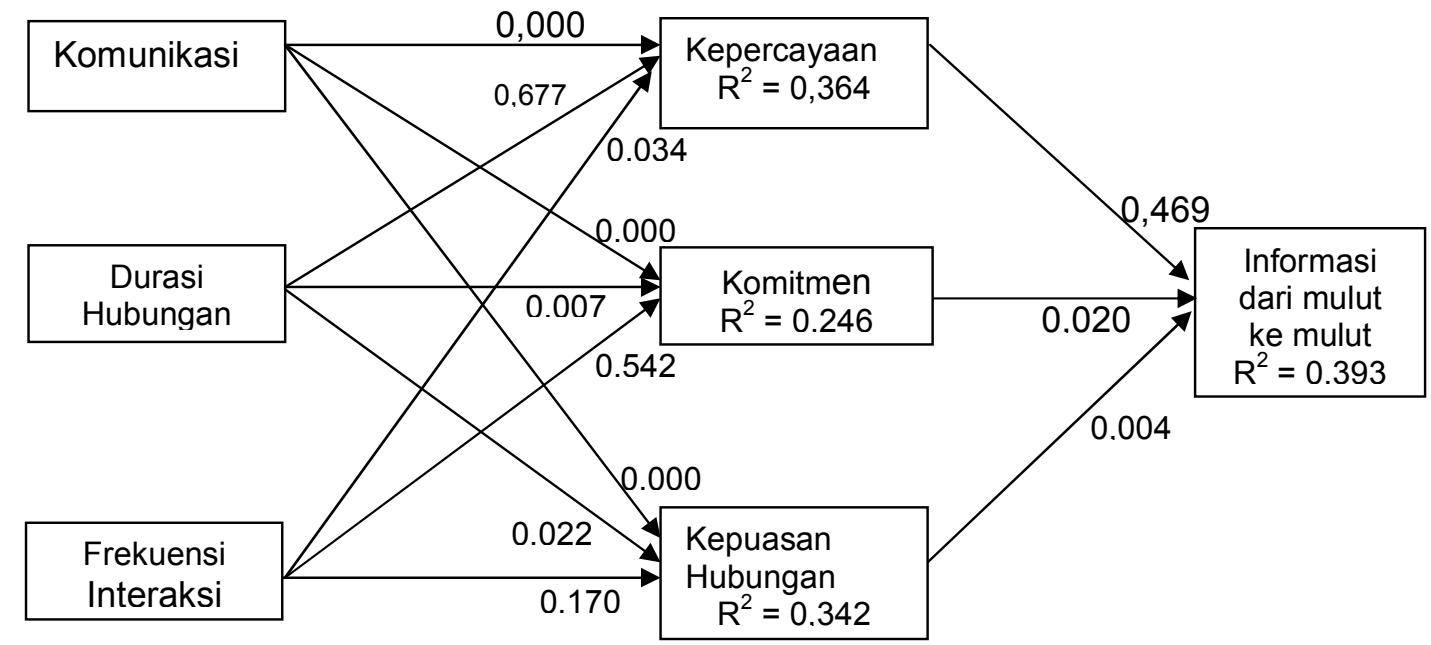

Gambar 2. Hasil Analisis Multivariat

Hasil penelitian kualitatif menjelaskan bahwa faktor yang mempengaruhi keraguan pelanggan untuk memanfaatkan pelayanan perawatan kulit di RS PKU Muhammadiyah Yogyakarta adalah (1) manfaat hubungan (pelanggan sudah memesan jauh hari namun saat datang masih harus antri dan menunggu); (2) kualitas pelayanan (tidak adanya obat yang tersedia di apotek dan treatment facial yang kurang nyaman); (3) keahlian penyedia (belum adanya hasil setelah melakukan perawatan dan kurangnya pengetahuan beautician dalam menjawab pertanyaan dari pelanggan), (4) kesamaan (pelanggan tidak cocok dengan produk di pelayanan perawatan kulit), (5) kemampuan menghargai pasien (pelanggan menginginkan facial namun dianjurkan konsultasi ke dokter) dan (6) persepsi harga (pelanggan merasa bahwa tarif konsultasi dokter kemahalan sedangkan di layanan perawatan lain berani member gratis untuk konsultasi dokter).

\section{PEMBAHASAN}

Komunikasi yang sering akan menghasilkan kepercayaan yang besar. Selain itu, untuk menghasilkan komitmen yang baik, penyedia layanan perlu melakukan komunikasi yang baik dengan pelanggan. Dan interaksi antara penjual dengan pelanggan dapat meningkatkan kepuasan pelanggan karena mendapatkan informasi yang relevan dan akurat mengenai suatu layanan.

Hasil penelitian menunjukkan bahwa durasi hubungan tidak memiliki asosiasi terhadap kepercayaan. Penelitian ini tidak sesuai dengan penelitian lain yang menunjukkan bahwa durasi hubungan memiliki pengaruh yang positif terhadap kepercayaan. Tidak adanya asosiasi antara durasi hubungan dengan kepercayaan mungkin dikarenakan pengukuran durasi hubungan. Dalam penelitian lain durasi hubungan yang menjadi responden minimal 6 bulan. Sedangkan penelitian ini pengukuran durasi hubungan tidak dilakukan melainkan melakukan pengukuran pada frekuensi interaksi sehingga mungkin hal tersebut yang menjadi alasan tidak adanya asosiasi antara durasi hubungan dengan kepercayaan. Walaupun dalam penelitian ini menjelaskan bahwa semakin lama durasi hubungan yang terjalin antara penyedia layanan dengan pelanggan maka akan menghasilkan kepercayaan yang baik.

Hasil penelitian menunjukkan bahwa durasi hubungan tidak memiliki asosiasi terhadap kepuasan hubungan. Hal ini tidak sesuai dengan penelitian Bolton (1998) yang menunjukkan bahwa pelanggan yang menggunakan pemasok yang sama untuk jangka waktu yang lama akan ada hubungan antara keduanya yaitu pelanggan memiliki tingkat kepuasan yang tinggi. Pernyataan tersebut sesuai dengan penelitian ini bahwa semakin lama durasi hubungan yang terjalin maka akan menghasilkan kepuasan hubungan yang baik. Sehingga dengan tingkat durasi hubungan yang berbeda akan mengakibatkan yang berbeda pula pada tingkat pengalaman konsumsi, memproduksi hasil, kepuasan dan loyalitas yang berbeda.

Hasil penelitian menunjukkan bahwa frekuensi interaksi tidak memiliki asosiasi terhadap kepuasan hubungan. Penelitian ini sesuai dengan penelitian Palmatier et al (2006). Keterbatasan penelitian Palmatier et al (2006) adalah tidak ditelitinya variabel saling ketergantungan yang merupakan aspek penting dalam relationship marketing dan adanya heterogenitas dalam pengukuran. Tidak adanya asosiasi antara frekuensi interaksi dengan kepuasan hubungan mungkin dikarenakan adanya keterpaksaan dari pelanggan untuk memanfaatkan layanan perawatan kulit di RS PKU Muhammadiyah Yogyakarta. Keterpaksaan muncul akibat dari keadaan tergantung kepada pihak lain. Keterpaksaan dapat mencapai persetujuan dari pihak lain namun demikian keterpaksaan yang berkelanjutan akan merusak komitmen dan kepercayaan dalam suatu hubungan. 
Dari pernyataan tersebut dapat pula menjawab hasil penelitian ini yang menunjukkan bahwa frekuensi interaksi tidak memiliki asosiasi terhadap komitmen.

Hasil penelitian menunjukkan bahwa kepercayaan tidak memiliki asosiasi terhadap informasi dari mulut ke mulut. Hal ini tidak sesuai dengan penelitian lain yang menyatakan bahwa semakin tinggi tingkat kepercayaan maka kecenderungan yang lebih besar untuk menawarkan informasi dari mulut ke mulut. Namun dalam penelitian ini menjelaskan bahwa kepercayaan yang baik menghasilkan informasi dari mulut ke mulut yang baik pula. Dalam penelitian Gremler et al (2001), pelanggan yang dijadikan responden adalah pelanggan yang memiliki durasi hubungan yang lama dengan penyedia layanan. Sehingga tidak adanya asosiasi antara kepercayaan terhadap informasi dari mulut ke mulut dikarenakan pelanggan yang menjadi responden adalah pelanggan yang memiliki durasi hubungan singkat dengan penyedia layanan.

Hasil penelitian kuantitatif menunjukkan nilai $\mathrm{R}^{2}$ yang relatif rendah pada kepercayaan, komitmen, kepuasan hubungan dan informasi dari mulut ke mulut (gambar 2). Artinya terdapat variabel lain yang tidak dijelaskan dalam model multivariat penelitian ini. Dan

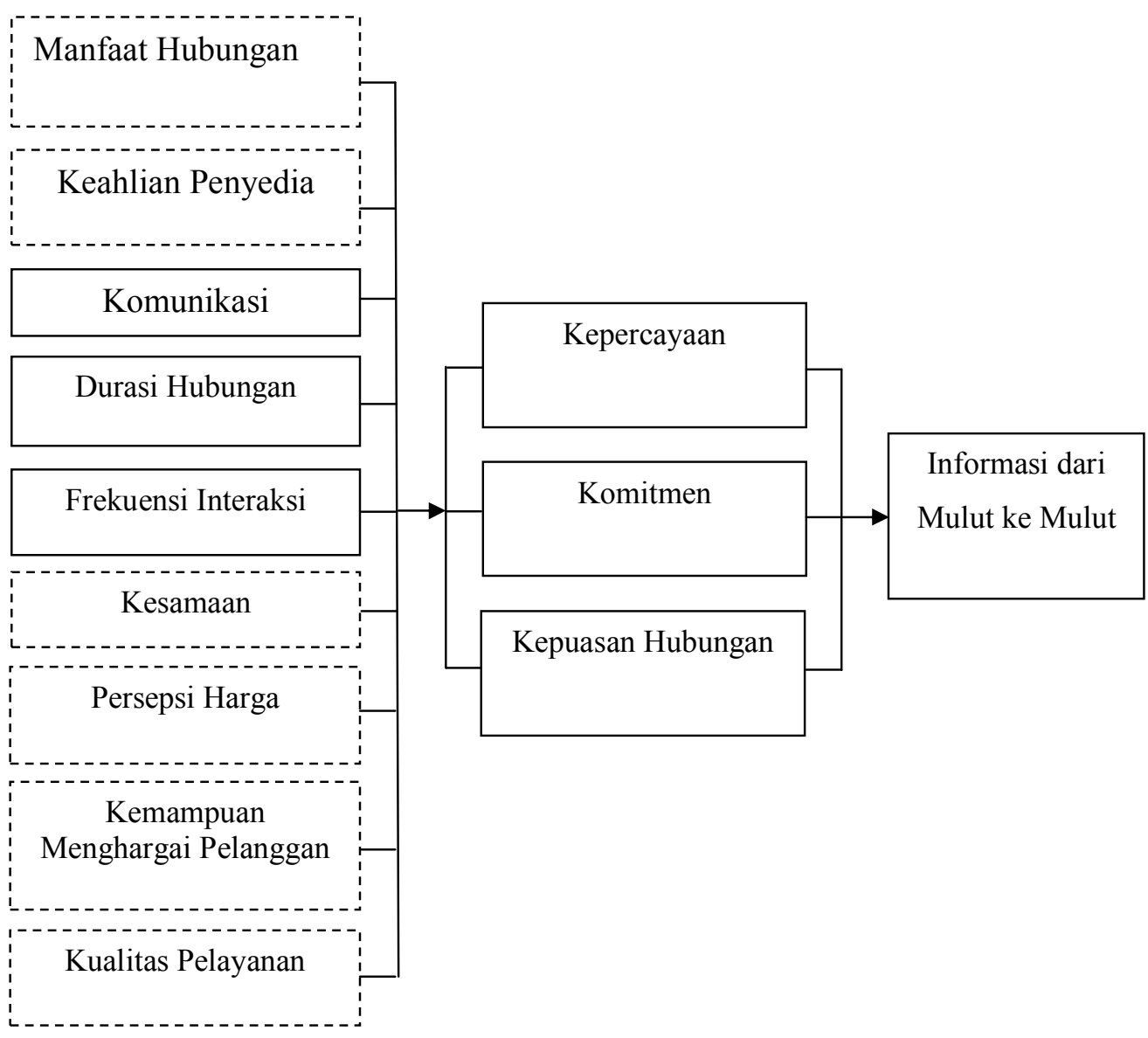

Gambar 3.

Model Teori Relationship Marketing pada Pelayanan Perawatan Kulit RS PKU Muhammadiyah Yogyakarta variabel lain yang tidak terdapat dalam model multivariat, dapat dijelaskan dengan penelitian kualitatif dalam penelitian ini meliputi manfaat hubungan, kualitas pelayanan, keahlian penyedia, persepsi harga, kemampuan menghargai pelanggan dan kesamaan. Kemungkinan variabel tersebut dapat berasosiasi terhadap kepercayaan, komitmen dan kepuasan hubungan pada relationship marketing di pelayanan perawatan kulit di RS PKU Muhammadiyah Yogyakarta.

Kualitas hubungan (kepercayaan dan kepuasan) ditingkatkan melalui kompetensi penyedia dan keahlian mempengaruhi hubungan jangka panjang. Selain itu, persepsi harga berpengaruh pada kepuasan pelanggan dan kepercayaan. Tidak hanya itu saja, penyedia layanan yang responsif dan empati relatif penting untuk kepuasan pelanggan terutama dalam pertemuan yang melebihi tiga puluh menit. Dan seorang pelanggan akan mengevaluasi dan menilai sebuah merek jika sebuah merek memiliki kesamaan dengan dirinya sendiri. Jika personality fisik merek dinilai sama dengan self image pelanggan, kesukaan terhadap merek, pengalaman terhadap merek, kepuasan terhadap merek maka pelanggan kemungkinan mempercayai merek tersebut. 


\section{KESIMPULAN}

Komunikasi memiliki asosiasi terhadap kepercayaan, komitmen dan kepuasan hubungan. Untuk durasi hubungan memiliki asosiasi terhadap komitmen dan kepuasan hubungan. Sedangkan frekuensi interkasi memiliki asosiasi terhadap kepercayaan. Dan untuk informasi dari mulut ke mulut memiliki asosiasi terhadap komitmen dan kepuasan hubungan.

\section{DAFTAR PUSTAKA}

Amelia, R (2008) Prinsip Pemasaran Nathan Kauffman Apakah Tepat atau Tidak Diterapkan pada Pemasaran Rumah Sakit di Indonesia (Manajemen Strategik Rumah Sakit. Medan. USU Repository

Wood, V., Bhuian, S \& Kiecker, P. (2000) Market Orientation and Organizational Performance in Not For Profit Hospitals. Journal of Business Research, 48, pp 213-226

Setyaningsih, P. (2009) Analisis Pasar Pendirian "Women Health Clinic" RS PKU Muhammadiyah Yogyakarta. Tesis, Universitas Gadjah Mada.

Leger, St., Schnieden, H \& Walsworth-Bell,S. (1993) Evaluating Health Service Effectiveness. Open University Press, Philadelphia

Widajat, Rochmanadji. (2009) Being A Great and Sustainable Hospital. Jakarta : PT Gramedia Pustaka Utama

Morgan, R \& Hunt, S (1994) The Commitment-Trust Theory of Relationship Markeing. Journal of Marketing, 58 (7), pp. 20-38.

Crosby, L., Evans, K. \& Cowles, D. (1990) Relationship Quality in Services Selling: An Interpersonal Influence Perspective. Journal of Marketing, 54 (7), pp. 68-81

Palmatier, R., Dant, R., Grewal, D \& Evans, K. (2006) Factors Influencing the Effectiveness of
Relationship Marketing : A Meta-Analysis. Journal of Marketing, 70 (10), pp. 136-153

Creswell JW \& Clark VLP. (2007) Designing and Conducting Mixed Methods Research. London : Sage Publications

Goff, B., James, S., Danny, N \& Carrie, S. (1997) The Influence of Salesperson Selling Behaviors on Customer Satisfaction with Product. Journal of Retailing, 73 (4), pp. 171-184

Anderson, E. \& Weitz, B. (1989) Determinants of Continuity in Conventional Industrial Channel Dyads. Marketing Science, 8, pp. 310-23.

De Wulf, K., Odekerken-Schroder, G \& Lacobucci, D. (2001) Investments in Consumer Relationships : A Cross-Country and Cross-Industry Exploration. Journal of Marketing, 65 (10), pp. $33-50$

Ranaweera, C., \& Prabhu, J. (2003). On the Relative Importance of Customer Satisfaction and Trust as Determinants of Customer Retention and Positive Word of Mouth. Journal of Targeting, Measurement and Analysis of Marketing, 12(1), pp. $82-90$.

Gremler, D., Gwinner, K., \& Brown, S. (2001). Generating Positive Word-of-Mouth Communication Through Customer Employee Relationships. International Journal of Service Industry Management, 12(1), pp. 44-59.

Peng, L \& Wang, Q (2006). Impact of Relationship Marketing Tactics (RMTs) on Switchers and Stayers in a Competitive Service Industry, Journal of Marketing Management. 22, pp.2559.

Price, L., Arnould, E. \& Tierney,P (1995). Going to Extremes: Managing Service Encounters and Assessing Provider Performance. Journal of Marketing. 59 (4), pp. 83-97.

Lau, G. \& Lee, S. (1999) Consumers' Trust in a Brand and the Link to Brand Loyalty. Journal of Market Focused Management, . 4, pp. 341-370 